\title{
Evaluation of materno-fetal antibody transfer in patients with antiphospholipid syndrome
}

\author{
Magda Carneiro-Sampaio ${ }^{1}$, Jozélio Freire de Carvalho*2 \\ ${ }^{1}$ Institute for Children Research, University of São Paulo, São Paulo, Brazil \\ ${ }^{2}$ Institute for Health Sciences, Federal University of Bahia, Bahia, Brazil
}

Received: December 27, 2020

Accepted: September 7, 2021

Online Published: October 14, 2021

DOI: $10.5430 /$ dcc.v8n3p22

URL: https://doi.org/10.5430/dcc.v8n3p22

\begin{abstract}
Introduction: Antiphospholipid syndrome (APS) is characterized by thrombotic events and recurrent pregnancy losses and is considered the most common acquired thrombophilia. Objective: To carry out a narrative review of the transplacental passage and antibodies in patients with APS.

Methods: A narrative literature review

Results: When it is not associated with any connective tissue disease, it is said to be primary, and when in association with systemic lupus erythematosus, it is said to be secondary. Gestational morbidity is frequent, and it is crucial to evaluate the passage of these antibodies transplacentally since there are animal models of the syndrome with passive transfer of these antibodies. The transplacental passage of specific antibodies has already been determined in studies, which demonstrated low levels of these antibodies in the maternal serum, but an efficient transplacental passage for the newborn.

Conclusions: There are few studies on this maternal-infant passage in patients with APS reviewed here.
\end{abstract}

Key Words: Antiphospholipid syndrome, Transplacental passage, Autoantibodies

\section{INTRODUCTION}

\subsection{Antiphospholipid syndrome and transplacental pas- sage}

Antiphospholipid syndrome (APS) is an autoimmune disease characterized by recurrent thrombotic events, pregnancy losses, and thrombocytopenia associated with antiphospholipid antibodies (anticardiolipin, lupus anticoagulant, and anti-beta2-glycoprotein I). ${ }^{[1]}$ Primary APS is defined as the antiphospholipid presence in patients with idiopathic thrombosis but no evidence of autoimmune disease or other triggering factors such as infection, malignancy, hemodialysis, or drug-induced antiphospholipids. ${ }^{[2]}$

Antiphospholipid antibodies' prevalence ranges from $1 \%$ to
$5 \%$ in apparently healthy individuals, increasing with age, especially in older individuals with chronic diseases. ${ }^{[3]}$ The average age of onset of clinical manifestations of the disease occurs at 31 years of age. ${ }^{[4]}$ The most common clinical presentations of the syndrome are deep venous thrombosis $(31.7 \%)$, thrombocytopenia $(21.9 \%)$, stroke $(13.1 \%)$, superficial thrombophlebitis $(9.1 \%)$, pulmonary embolism $(9$, $0 \%)$, fetal loss $(8.3 \%)$, transient ischemic attack $(7.0 \%)$ and hemolytic anemia $(6.6 \%)$. Treatment is based on prolonged anticoagulation in most cases.

Several studies have shown that antiphospholipid antibodies are associated with increased spontaneous abortions and fetal death. In addition, these antibodies' pathogenic role has

*Correspondence: Jozélio Freire de Carvalho; Email: jotafc@gmail.com; Address: Rua das Violetas, 42, ap. 502, Pituba, Salvador, Bahia, Brazil. 
also been proven in experimental models that, when infused during pregnancy, placental insufficiency and abortions were observed. ${ }^{[5]}$ Also, antiphospholipid antibodies can bind the cells of the trophoblastic tissue, changing their function. ${ }^{[6]}$

Intraplacental thrombosis does not seem to be the only mechanism of fetal losses; these studies have shown the alteration of trophoblastic cells and placental lesions mediated by the complement system. Di Simone suggested that trophoblastic invasion abnormalities are observed in the first trimester and appear to be due to changes in differentiation, maturation, secretion reduction, and human chorionic gonadotropins6. Interestingly, beta2-glycoprotein I has already been found in cell membranes trophoblastic, which could justify this tissue as the target of antiphospholipid antibodies. ${ }^{[7]}$

In addition to fetal losses, delayed intrauterine growth (CIUR), placental insufficiency, pre-eclampsia, and eclampsia have been observed in women with APS. ${ }^{[8]}$

At birth, the baby has an immaturity of its immune system, which will take some time to develop. Therefore, transplacental passage and breastfeeding will provide the newborn with immediate protection.

The human placenta is a selective barrier for transferring from the mother to the fetus of several macromolecules, including immunoglobulins. Maternal IgG antibodies passively acquired by the placenta protect the neonate from many pathogens. ${ }^{[9,10]}$ It is now known that the transport of IgG through the placenta in humans begins around the twentieth week of gestation, increases after the third trimester, and progressively increases until the term. ${ }^{[11,12]}$

Only antibodies of the IgG class cross the placental barrier, and the rate of transmission of these immunoglobulins varies according to the subclass to which they belong. For example, IgG1 and IgG3 cross the placenta a little more efficiently than IgG4, which, in turn, transposes the maternal-fetal interface more efficiently than IgG2. ${ }^{[13]}$

The IgG molecule needs to overcome at least two barriers from the maternal circulation towards the fetal circulation: the syncytiotrophoblast and the fetal capillary endothelium. In some regions of the term placenta, these two structures are separated only by the basal lamina; in others, villous stromal cells and some cytotrophoblasts are also present. ${ }^{[2]}$

The transport of maternal IgG through the human placenta is a process that occurs as follows: IgG molecules penetrate the syncytiotrophoblast by pinocytosis and bind to receptors present on the inside of these vesicles - receptors that, before the pinocytosis process, found on the microvillous surface of the syncytiotrophoblast. Protected from lysosomal enzymes' action, the IgG molecules coupled to the receptors are then transported to the trophoblastic basal lamina. Once in the extracellular matrix, the IgG molecules gain access to the fetal endothelium and, thus, to the fetal circulation. ${ }^{[14]}$ However, it is known that not all maternal IgG reaches the fetal circulation: molecules that do not bind to receptors in the carrier vesicles will be digested by lysosomal enzymes. ${ }^{[11,15]}$

Several candidates for the Fc portion's receptor responsible for the transport of the IgG molecule have already been studied. ${ }^{[16,17]}$ The neonatal IgG receptor (FcRn), accountable for IgG transport from the mother to the fetus, is a protein formed from two polypeptide chains: a heavy chain similar to class I central histocompatibility complex molecule and another light chain which is b2-microglobulin. ${ }^{[18,19]}$ However, the current knowledge about the transplacental transport of $\mathrm{IgG}$ at the molecular level in humans is still incomplete. Evidence suggests a role for FcRn in maternal IgG transport through syncytiotrophoblast; however, as this receptor does not seem to be present in the fetal capillary endothelium, how the IgG molecule reaches the fetal circulation.

Few studies have evaluated the transplacental passage of antiphospholipid antibodies. The authors verified the path of anticardiolipin IgG, which is small and decreases over time, almost disappearing at six months7. Besides, while anticardiolipin antibodies are negative at 13 months, anti- $\beta 2$ GPI antibody titers may be significantly elevated, presumably due to response to infections or antigens. ${ }^{[20]}$ This finding was also observed in children of comparable age to daughters with antiphospholipid negative hands. ${ }^{[21]}$

There are still about 20 neonatal APS cases described; that is, the child after birth presents severe thrombosis related to the transplacental passage of antiphospholipid antibodies. ${ }^{[22]}$

\subsection{Breast-feeding}

Extensive epidemiological studies have shown that breastfeeding is an efficient process of protecting children against infectious diseases. ${ }^{[23]}$ Colostrum is the neonate's first line of defense, capable of stimulating its immune system. It is defined as the breast secretion collected in the first 2 to 3 days of lactation or up to one week after delivery. ${ }^{[24]}$ Mucous surfaces are a boundary between the internal and external environments, representing a gateway to most infections in humans. For this reason, mucous surfaces have a very efficient anti-infectious protection system, where non-specific mechanisms such as peristaltic movement, mucociliary transport, and enzymes act, and adaptive mechanisms are mainly represented by the mucosal immune system (MALT, Mucosal associated lymphoid tissue). It consists of immunocompetent cells that infiltrate the mucous membranes. These lymphoid 
nodules come from Peyer's plaque-like structures in the intestinal mucosa and their equivalents in the bronchial mucosa, in addition to regional lymph nodes, such as the mesenteric ones. MALT is populated by cells from different subpopulations, with varied functions, including that of producing secretory antibodies, with an absolute predominance of $\operatorname{sIgA}$, which, through the epithelium, will be incorporated into the mucus that covers all mucous surfaces of the organism. ${ }^{[25]}$ The standard mucosal immune system in the newborn is not yet mature. Peyer's plaques contain only primary germinal centers; the B cells produce only IgM, few T cells, and virtually no memory cells are found. In particular, in the gastrointestinal tract, the immaturity of the epithelium allows more excellent permeability for macromolecules and provides more outstanding adhesion of microorganisms. The low gastric acidity and lower digestive enzyme activity still do not represent such an efficient barrier compared to the adult organism. ${ }^{[26]}$ The secretory immunoglobulin ( $\left.\operatorname{sIgA}\right)$ is considered the most critical molecule involved in protecting newborns against pathogens or toxins and is most abundant in colostrum. ${ }^{[27]}$ These antibodies' function is to act locally, promoting the inhibition of pathogen adhesion on the child's mucous surfaces. IgA has a peculiar structure, remarkably adapted to work in the conditions of mucous surfaces: it is generally polymeric (dimeric or trimeric), being associated with the $\mathrm{J}$ chain (synthesized by plasma cells) and the secretory component (produced by the epithelial cell), constituting a complex with high avidity for binding to antigens and more excellent resistance to the action of proteolytic enzymes, abundant in mucous secretions. ${ }^{[25,28]}$ IgA class antibodies are produced by plasmocytes present in the lamina propria underlying the epithelium and generally released as dimers linked to the $\mathrm{J}$ chain in the vicinity of the basolateral portion of epithelial cells, where receptors for polymeric immunoglobulin are present. These receptors are glycoproteins of about $100 \mathrm{kDa}$, belonging to the immunoglobulin superfamily, and are constitutively expressed in the basolateral membrane of secretory epithelial cells. The expression of these receptors can be stimulated by cytokines such as IFN-g (interferon-gamma). ${ }^{[25]}$ IgA dimers bind to the receptor, and an internalization process begins by endocytosis. Thus, the polymeric immunoglobulin crosses the epithelial layer and is secreted in the cell's apical portion, where cleavage of the receptor and a small transmembrane C-terminal fragment that remains in the epithelial cell is degraded. In contrast, the more significant extracellular amount is incorporated into the IgA-J chain complex as a secretory component. This mechanism of IgA secretion occurs on the surfaces of the oral, intestinal, bronchial mucosa, and mammary glands during lactation.
Two subclasses of $\operatorname{IgA}$ are known: $\operatorname{IgA} 1$ and $\operatorname{IgA} 2$. $\operatorname{IgA} 1$ comprises about $80 \%$ to $85 \%$ of total serum $\operatorname{IgA}$, where it is found in the form of monomers. It is found only in the nasal mucosa and tonsils. It can suffer the action of proteases produced by some pathogenic bacteria such as Haemophilus, Neisseria, and Streptococcus, which act on amino acid sequences in the immunoglobulin region hinge. The IgA2 subclass may favor secretory antibodies' stability because this isotype is resistant to several bacterial proteases specific for IgA. After all, it has a deletion in the hinge's amino acid sequences, which favors its adaptation, especially in intensely colonized sites, such as the colon and the pharynx. However, in secretions, the two subclasses are found in more balanced proportions, varying slightly from one place to another. ${ }^{[29,30]}$

$\operatorname{IgM}$ is the second most abundant immunoglobulin in mucous membranes, in concentrations of $2.5 \mathrm{mg} / \mathrm{ml}$. Its affinity for the receptor for polymeric immunoglobulin on the basolateral surface of epithelial cells allows its secretion in the polymeric form linked to the secretory component. Thus, highly avid IgM antibodies reactive with viruses and bacteria can play an essential role in defending the infant's mucosal surfaces. In particular cases of IgA deficiency, a compensation mechanism occurs. The secretion of polymeric IgM linked to the $\mathrm{J}$ chain, which has an affinity for the secretory component, can supply the lack of sIgA.

IgG is found in low concentrations in human milk, about 0.1 $\mathrm{mg} / \mathrm{ml}$, has opsonizing activity, and can activate complement and antibody-dependent cytotoxicity, which is an activity that is rarely present on the infant's mucosal surfaces. Only IgG2 and IgG4 are present in higher concentrations than in serum, perhaps to cover the newborn's lack of production of these subclasses.

In human milk, there are several biochemical factors with anti-infectious action such as enzymes, cytokines, components of the complement system, cells, oligosaccharides, nucleotides, lipids, and hormones, which interact with each other and with the mucous membranes of the newborn's digestive and respiratory tracts, in addition to passive immunity, stimulating the development and maturation of the newborn's immune system. ${ }^{[31,32]}$ It is also suggested that human milk may protect against other infections and diseases including autoimmune diseases, such as respiratory and urinary tract infections. Necrotizing enterocolitis, atopic diseases, type 1 diabetes, multiple sclerosis, rheumatoid arthritis, celiac disease, and Crohn's disease; however, there are controversial studies in this regard. ${ }^{[23,33]}$ Many studies are still needed to ensure a real protective factor against autoimmune diseases. However, the beneficial effects of breast milk for optimal growth, development, and protection against infec- 
tious agents are sufficient reasons to encourage breastfeeding, thus improving children's health conditions.

There are no studies in APS that have evaluated antiphospholipid antibodies in breast milk.

\section{Conclusion}

Few studies have evaluated the transplacental passage of antiphospholipid antibodies. The passage of anticardiolipin
IgG was verified, and it reduced over time, almost disappearing at six months. There are also some cases of neonatal APS related to the transplacental passage of antiphospholipid antibodies. There are no studies in APS that have evaluated antiphospholipid antibodies in breast milk.

\section{CONFLicts OF INTEREST Disclosure}

The authors declare they have no conflicts of interest.

\section{REFERENCES}

[1] Andrews R, et al. Pertussis notifications in Australia, 1991 to 1997. Commun Dis Intell. 1997; 21: 145-148.

[2] Benirschke K, Kaufmann P, et al. Early development of the human placenta. In: Pathology of the human placenta. 3rd ed. New York: Springer-Verlag. pp. 49-56. 1995. https : //doi .org/10.1007/97 8-1-4757-4196-4_6

[3] Baron S, Njamkepo E, Grimprel E, et al. Epidemiology of pertussis in French hospitals in 1993 and 1994: thirty years after a routine use of vaccination. Pediatr Infect Dis J. 1997; 17: 412-418. PMid:9613656. https://doi.org/10.1097/00006454-199805000-00013

[4] Belloni C, Silvestri AD, Tinelli C, et al. Immunogenicity of a threecomponent acellular pertussis vaccine administered at birth. Pediatrics. 2003; 111: 1042-1045. PMid:12728086. https : //doi.or g/10.1542/peds.111.5.1042

[5] Tincani L, et al. Shoenfeld, Animal models of antiphospholipid syndrome. Rev Rheum. 1998; 56: 614-618.

[6] Simone ND, Meroni PL, Papa ND, et al. Antiphospholipid antibodies affect trophoblast gonadotropin secretion and invasiveness by binding directly and through adhered $\beta 2$-Glicoprotein I. Arthritis Rheum. 2000; 43: 140-150. https://doi .org/10.1002/1529-0131(20 0001) $43: 1<140:$ : AID-ANR18>3. 0.CD; 2-P

[7] Zurgil N, Bakimer R, Tincani A, et al. Detection of antiphospholipid and anti-DNA antibodies and their idiotypes in newborns of mothers with antiphospholipid sindrome and SLE. Lupus. 1993; 2 : 233-237. PMid:8268971. https://doi.org/10.1177/09612033 9300200405

[8] Tincani A, Balestrieri G, Danieli E, et al. Pregnancy complications of the antiphospholipid syndrome. Autoimmunity. 2003; 36: 27-32. PMid:12765468. https://doi.org/10.1080/08916930310000 67278

[9] Healy CM, Munoz FM, Rench MA, et al. Prevalence of pertussis antibodies in maternal delivery, cord, and infant serum. The Journal of Infectious Diseases. 2004; 190: 335-40. PMid:15216470. https://doi.org/10.1086/421033

[10] Miller ME, et al. Immunology and resistance to infection. In Remington, JS, Klein JO. Infectious diseases of the fetus and newborn infant, 2nd ed. Philadelphia: W B Sanders Co; 1983.

[11] Saji F, Koyama M, Matsuzaki N. Human placental Fc receptors. Placenta. 1994; 15: 453-66. https://doi.org/10.1016/S0143-4 004 (05) 80415-1

[12] Simister NE. Placental transport of immunoglobulin G. Vaccine. 2003; 21: 3365-3369. https://doi.org/10.1016/S0264-410 $\mathrm{X}(03) 00334-7$

[13] Rote NS. Maternal-fetal immunology. In: Scott JR and Rote NS. Immunology in Obstetrics and Gynecology. Norwalk: Appleton. p.55-75. 1985.

Published by Sciedu Press
[14] Story CM, Mikulska JE, Simister NE. A major histocompatibility complex class I-like Fc receptor cloned from human placenta: possible role in transfer of immunoglobulin $\mathrm{G}$ from mother to fetus. $\mathrm{J}$ Exp Med. 1994;180: 2377-81. PMid:7964511. https ://doi.org/ 10.1084/jem.180.6.2377

[15] Johnson PM, Brown PJ. Fc $\gamma$ receptors in the human placenta. Placenta. 1981; 2: 355-70. https://doi.org/10.1016/S0143-400 4 (81) $80031-8$

[16] Kristoffersen EK, Ulvestad E, Vedeler CA, et al. Ulvestad E, Veleder GA, Matre R. Fcg receptor heterogeneity in the human placenta. Scand J Immunol. 1990; 31: 561-4. PMid:2148639. https ://doi . org/10.1111/j.1365-3083.1990.tb03197.x

[17] Bright NA, et al. Ontogeny and distribution of Fcg receptors in the human placenta. Transport or immunosurveillance? J Anat. 1994; 184: 297-308.

[18] Kristoffersen EK, Matre R. Co-localization of b 2-microglobulin and $\mathrm{IgG}$ in human placental syncytiotrophoblast. Eur J Immunol. 1996; 26: 505-7. PMid:8617324. https://doi.org/10.1002/eji.18 30260234

[19] Simister NE, Story CM, Chen HL, et al. An IgG-transporting Fc receptor expressed in the syncytiotrophoblast of human placenta. Eur J Immunol. 1996; 26: 1527-31. PMid:8766556. https ://doi .or g/10.1002/eji.1830260718

[20] Motta M, et al. Anticardiolipin and anti-beta 2 glycoprotein I in infants born to mothers with and without antiphospholipid antibodies (abstract). Arthritis Rheum. 2004; 50: s69.

[21] Avčin T, Ambrožič A, Kuhar M, et al. Anticardiolipin and anti-beta 2 glycoprotein I antibodies in sera of 61 apparently healthy children at regular preventive visits. Rheumatology. 2001; 40: 565-573. PMid:11371668. https://doi .org/10.1093/rheumatology/4 0.5 .565

[22] Boffa MC, Lachassinne E. Infant perinatal thrombosis and antiphospholipid antibodies: a review. Lupus. 2007; 16(8): 634-41. PMid:17711900. https://doi.org/10.1177/09612033070790 39

[23] Hanson LA, et al. Immunobiology and epidemiology of breastfeeding in relation to prevention of infections from a global perspective. In: Ogra PL, Mestecky J, Lamm ME, Strober W, Bienenstock J \& McGhee JR, eds. Mucosal Immunology. 2nd ed. Academic Press. pp. 1501-1510. 1999.

[24] Islam SKN, Ahmed L, Khan NI, et al. Immune components (IgA, IgM, IgG, immune cells) of colostrum of Bangladeshi mothers. Pediatrics International. 2006; 48: 543-548. PMid:17168971. https : //doi.org/10.1111/j.1442-200X.2006.02291.x

[25] Brandtzaeg P. Molecular and cellular aspects of the secretory immunoglobin system. APMIS. 1995; 103: 1-19. PMid:7695886. https://doi.org/10.1111/j.1699-0463.1995.tb01073.x 
[26] Bernt KM, Walker WA, et al. Human milk as a carried of biochemical messages. Acta Paediatr Suppl. 1999; 430: 27-41. PMid:10569221. https://doi.org/10.1111/j.1651-2227.1999.tb01298.x

[27] Takahashi T, Yoshida Y, Hatano S, et al. Reactivity of secretory IgA antibodies in breast milk from 107 japanese mothers to 20 environmental antigens. Biol Neonate. 2002; 82: 238-242. PMid:12381931. https://doi.org/10.1159/000065893

[28] Russel MW, et al. Biological activities of IgA. In: Ogra PL, Mestecky J, Lamm ME, Strober W, Bienenstock J \& McGhee JR, eds. Mucosal Immunology. 2nd ed. Academic Press. pp. 225-240. 1999.

[29] Goldman AS, et al. Anti-infectious and infectious agents in human milk. In: Ogra PL, Mestecky J, Lamm ME, Strober W, Bienenstock J \& McGhee JR, eds. Mucosal Immunology. 2nd ed. Academic Press. pp. 1511-1521. 1999.
[30] Brandtzaeg P, Johansen FE. Mucosal B cells: phenotypic characteristics, transcriptional regulation, and homing properties. Immunological Reviews. 2005; 206: 32-63. PMid:16048541. https : //doi.org/10.1111/j.0105-2896.2005.00283.x

[31] Barros MD, Porto MH, Leser PG, et al. Study of colostrum of a patient with selective IgA deficiency. Allergol Immunopathol (Madr). 1985; 13(4): 331-4.

[32] Grumach AS, Carmona RC, Lazarotti D, et al. Immunological factors in milk from Brazilian mothers delivering small-for-date term neonates. Acta Paediatr. 1993; 82: 284-90. PMid:8388277. https ://doi.org/10.1111/j.1651-2227.1993.tb12661.x

[33] Hanson LA. Breastfeeding provides passive and likely long-lasting active immunity. Ann Allergy Asthma Immunol. 1998; 81: 523-537. https ://doi .org/10.1016/S1081-1206(10)62704-4 